\title{
PEMBUATAN ALAT UJI KEKENTALAN MINYAK GORENG DENGAN MENGGUNAKAN METODE VISKOSITAS STOKES UNTUK PRAKTIKUM FISIKA DASAR 1 JURUSAN TADRIS FISIKA FAKULTAS ILMU TARBIYAH DAN KEGURUAN IAIN WALISONGO
}

\section{Agus Sudarmanto}

\section{Abstrak}

Penelitian ini merancang dan merealisasikan pembuatan alat uji kekentalan minyak goreng dengan metode viskositas stokes dan indeks bias.

Pembuatan alat uji kekentalan minyak goreng dengan metode viskositas stokes terdiri dari sumber cahaya, sensor cahaya yang keluarannya diproses dengan mikrokontroler ATMega8535 dengan algoritma program kemudian hasilnya ditampilkan pada LCD (Liquid Cristal Display).

Hasil penelitian ini adalah bahwa pembuatan alat uji kekentalan minyak goreng dengan metode viskositas stokes dan indeks bias pada praktikum Tadris Fisika Fakultas Tarbiyah IAIN Walisongo Semarang sudah dapat berfungsi sesuai dengan yang diinginkan dan data nilai viskositasnya yaitu sebesar $4,80 \times 10-3 \mathrm{Ns} / \mathrm{m}^{2}$.

Kata kunci : sensor cahaya, mikrokontroler, viskositas 


\section{PENDAHULUAN}

Minyak merupakan zat makanan yang penting untuk menjaga kesehatan tubuh manusia. Selain itu minyak juga merupakan sumber energi yang lebih efektif dibandingkan karbohidrat dan protein. Satu gram minyak dapat menghasilkan $9 \mathrm{kkal}$, sedangkan karbohidrat dan protein hanya menghasilkan $4 \mathrm{kkal} /$ gram. Minyak, khususnya minyak nabati, mengandung asam-asam lemak esensial seperti asam linoleat, lenolenat, dan arakidonat yang dapat mencegah penyempitan pembuluh darah akibat penumpukan kolesterol. Minyak juga berfungsi sebagai sumber dan pelarut bagi vitaminvitamin A, D, E dan K. (Ketaren. S, 1986)

Minyak terdapat pada hampir semua bahan pangan dengan kandungan yang berbeda-beda. Dalam pengolahan bahan pangan, minyak berfungsi sebagai media penghantar panas, seperti minyak goreng, mentega dan margarin. Minyak goreng adalah salah satu kebutuhan pokok masyarakat Indonesia dalam rangka pemenuhan kebutuhan sehari-hari. Minyak goreng yang kita konsumsi seharihari sangat erat kaitannya dengan kesehatan kita.

Parameter kualitas minyak meliputi sifat fisik dan sifat kimia. Sifat fisik minyak meliputi warna, bau, kelarutan, titik cair dan polimorphism, titik didih, titik pelunakan, bobot jenis, viskositas, indeks bias, titik kekeruhan (turbidity point), titik asap, titik nyala dan titik api. Parameter yang digunakan dalam penelitian ini yaitu berdasarkan sifat fisik minyak yaitu viskositas dan indeks bias.

Standar mutu adalah merupakan hal yang penting untuk menentukan minyak yang bermutu baik. Ada beberapa faktor yang menentukan standar mutu yaitu : kandungan air dan kotoran dalam minyak, kandungan asam lemak bebas, warna, dan bilangan peroksida. Faktor lain yang mempengaruhi standar mutu adalah titik cair dan kandungan gliserida, kejernihan kandungan logam berat, dan bilangan penyabunan. Mutu minyak kelapa sawit yang baik mempunyai kadar air kurang dari 0,1\% dan kadar kotoran lebih kecil dari 0,01\%, kandungan asam lemak bebas serendah mungkin (kurang lebih $2 \%$ atau kurang), bilangan peroksida dibawah 2, bebas dari warna merah dan kuning (harus berwarna pucat) tidak berwarna hijau, jernih, dan kandungan logam berat serendah mungkin 
atau bebas dari ion logam. (Ketaren. S, 1986)

Studi tentang minyak goreng sebelumnya telah dilakukan oleh Istianah (Sutiah, 2008), dengan parameter perubahan sudut polarisasi terhadap berkas sinar yang ditransmisikan. Dari penelitian tersebut secara kualitatif ditunjukkan bahwa minyak goreng yang mempunyai kualitas paling baik adalah minyak goreng dengan efek perubahan sudut polarisasi yang paling kecil dibanding yang lain. Pada penelitian ini secara R \& D hendak menunjukkan bahwa minyak goreng yang mempunyai kualitas paling baik yaitu minyak goreng dengan nilai viskositas.

\section{KERANGKA TEORI}

Diode pancaran cahaya (bahasa Inggris: light-emitting diode; LED) adalah suatu semikonduktor yang memancarkan cahaya monokromatik yang tidak koheren ketika diberi tegangan maju. Gejala ini termasuk bentuk elektroluminesensi. Warna yang dihasilkan bergantung pada bahan semikonduktor yang dipakai, dan bisa juga ultraviolet dekat atau inframerah dekat. (http://id.wikipedia.org/ wiki/Diode_pancaran_cahaya, 2013)

Masalah utama dalam teknik pengukuran dan pengaturan secara elektronik adalah mengubah besaran fisik (misal : temperatur, kecepatan ayunan) menjadi besaran listrik yang proporsional. Pengubah yang melaksanakan hal ini secara mum disebut sebagai sensor. Sensor fotoelektrik terdiri dari atas LED berwarna merah atau LED infra merah yang menyinari fotodioda atau fototransistor sebagai penerimanya. Mereka tersedia sebagai satu kesatuan atau terpisah dalam masing-masing kotak. Kadang-kadang juga dilengkapi dengan lensa agar dapat mengenali sinyal kecil dengan lebih baik, atau untuk memperoleh jarak pengamatan yang lebih jauh. (Link, Wolfgang, 1993)

Mikrokontroler AVR (Alf and Vegard's Risc Processor) merupakan salah satu perkembangan produk mikroelektronika dari vendor Atmel. AVR merupakan teknologi yang memiliki kemampuan yang baik dengan biaya ekonomis yang cukup minimal. Mikrokontroler AVR memiliki arsitektur RISC 8 bit, dimana semua instruksi di- 
kemas dalam kode 16 bit dan sebagian besar instruksi dieksekusi dalam 1 (satu) siklus clock, berbeda dengan instruksi MCS51 yang membutuhkan 12 siklus clock. Tentu saja itu terjadi karena kedua jenis mikrokontroler tersebut memiliki arsitektur yang berbeda. AVR berteknologi RISC (Reduced Instruction Set Computing), sedang MCS 51 berteknologi CISC (Complex Instruction Set Computing). Secara umum AVR dapat dikelompokkan menjadi 4 kelas, yaitu keluarga ATiny, keluarga AT90Sxx, Keluarga ATMega, dan AT86RFxx. (Lingga. W, 2006)

Keypad 4x4 di sini adalah sebuah keypad dengan susunan empat baris dan empat kolom dengan sebuah common. Pada alat ini pin-pin pada keypad dihubungkan pada port B mikrokontroler ATMega8535. Keypad berfungsi untuk memasukkan data dan melakukan seting atau kontrol.

Kondisi tidak adanya penekanan tombol diatur dengan adanya kondisi logika high dengan menghubungkan semua pin keypad (kecuali common) ke VCC melalui resistor pull up. Pada saat tombol tidak ditekan, maka arus akan mengalir dari VCC melalui resistor menuju ke port. http://delta-electronic.com/article/wp-content/uploads/2008/09/an0060.pdf)

LCD Display modul M1632 buatan Seiko Inc, meskipun harganya sekitar lima kali lipat dibanding dengan LCD Module SEDI200 buatan Epson, tapi karena M1632 lebih dulu beredar di Indonesia dan lebih mudah didapat, masih merupakan pilihan banyak penggemar elektronik praktis. LCD display module M1632 terdiri dari dua bagian, yang pertama merupakan panel LCD sebagai media penampil informasi dalam bentuk huruf/angka dua baris, masing - masing baris bisa menampung 16 huruf/angka.

Bagian kedua merupakan sebuah sistem yang dibentuk dengan mikrokontroler yang ditempel dibalik pada panel LCD, berfungsi mengatur tampilan LCD. Dengan demikian pemakaian LCD M1632 menjadi sederhana, sistem lain cukup mengirimkan kode - kode ASCII dari informasi yang ditampilkan. (Malvino, A. P. 1992)

Viskositas adalah ukuran yang menyatakan kekentalan suatu cairan atau fluida. Kekentalan merupakan sifat cairan yang berhubungan erat dengan hambatan untuk mengalir. Beberapa cairan 
ada yang dapat mengalir cepat, sedangkan lainnya mengalir secara lambat. Cairan yang mengalir cepat seperti air, alkohol dan bensin mempunyai viskositas kecil. Sedangkan cairan yang mengalir lambat seperti gliserin, minyak castor dan madu mempunyai viskositas besar. Jadi viskositas tidak lain menentukan kecepatan mengalirnya suatu cairan.

Bila sebuah benda digerakkan pada permukaan zat padat yang kasar maka akan mengalami gaya gesekan. Analog dengan hal itu, maka sebuah benda yang bergerak dalam zat cair yang kental akan mengalami gaya gesekan yang disebabkan oleh kekentalan zat cair tersebut. Dalam hal ini gaya gesekan pada benda yang bergerak dalam zat cair kental dapat kita ketahui melalui besar kecepatan benda. Menurut hukum Stokes, gaya gesekan yang dialami oleh sebuah bola pejal yang bergerak dalam zat cair yang kental adalah :

$$
\mathrm{F}_{\mathrm{s}}=-6 \pi \eta \mathrm{rV}
$$

dengan :

Fs : gaya gesekan zat cair (kg.m.s. $\left.{ }^{-2}\right)$

h : koefisien kekentalan zat cair (N.m.2.s )

$\mathrm{r} \quad$ : jari-jari bola pejal $(\mathrm{m})$

$\mathrm{v}$ : kecepatan benda dalam zat cair $\left(\mathrm{ms}^{-1}\right)$

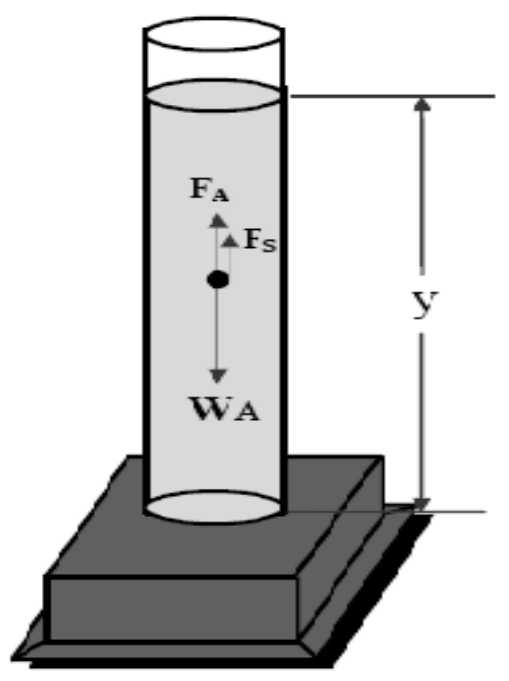

\section{Gambar 1 Alat viskositas \\ Ostwald}

Selain gaya gesekan zat cair, kita juga sudah mengenal gaya berat dan gaya keatas. Dengan demikian maka, pada sebuah bola pejal yang bergerak dalam zat cair yang kental (Gambar 1) akan mengalami ketiga gaya tersebut, yaitu; 


$$
\Sigma \mathrm{F}=\mathrm{W}+\mathrm{F}_{\mathrm{A}}+\mathrm{F}_{\mathrm{S}}
$$

Bila bola pejal telah mencapai kecepatan tetap, maka resultan ketiga gaya tersebut akan sama dengan nol, sehingga benda bergerak lurus beraturan. Besar kecepatannnya pada keadaan itu dapat dinyatakan dengan

$$
\mathrm{V}=\frac{2 \mathrm{r}^{2} \mathrm{~g}\left(\rho-\rho_{\mathrm{o}}\right)}{9 \eta}
$$

dengan:

g : percepatan gravitasi $\left(\mathrm{ms}^{-2}\right)$; gunakan $\mathrm{g}=9,87 \mathrm{~ms}^{-2}$

$\rho \quad$ : massa jenis bola pejal $\left(\mathrm{kg} \cdot \mathrm{m}^{-3}\right)$

$\rho_{0}$ : massa jenis zat cair $\left(\mathrm{kg} \cdot \mathrm{m}^{-3}\right)$

Bila selama bergerak lurus beraturan, bola memerlukan waktu selama t untuk bergerak sejauh y, maka persamaan (3) di atas dapat diubah menjadi ; (http://file.upi.edu/Direktori/FPMIPA/JUR._PEND._ FISIKA/ 196707251992032\%20-\%20SETIYA\%20UTARI/4_Viskositas. pdf, 2013)

$$
t=\frac{9 \eta y}{2 \mathrm{gr}^{2}\left(\rho-\rho_{\mathrm{o}}\right)}
$$

dengan :

t : waktu bola pejal jatuh (s)

y : tinggi cairan $(\mathrm{m})$

$\mathrm{r} \quad$ : jari-jari bola pejal $(\mathrm{m})$

$\eta \quad$ : viskositas cairan (kekentalan cairan)

\section{METODE PENELITIAN}

\section{Pembuatan Perangkat Keras}

Desain Pembuatan Alat Uji Kekentalan Minyak Goreng dengan Metode Viskositas Stokes untuk Praktikum Fisika Dasar 1 
Jurusan Tadris Fisika Fakultas Ilmu Tarbiyah dan Keguruan IAIN Walisongo dapat dilihat pada gambar di bawah ini.

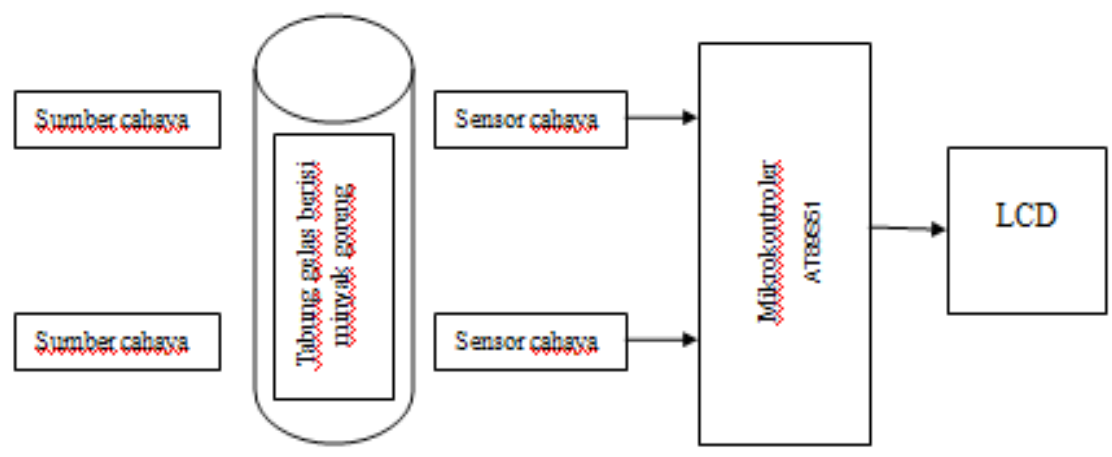

\section{Gambar 2. Perancangan alat uji kekentalan minyak goreng dengan memodifikasi viskositas otswald}

Cara kerja alat : bola besi (gotri) dimasukkan pada tabung gelas yang berisi minyak goreng, sensor 1 sebagai saklar on dan sensor 2 sebagai saklar off, kemudian sinyal keluaran dari kedua sensor tersebut diolah dengan algoritma pemrograman pada mikrokontroler sehingga keluaran pada LCD adalah nilai dari kekentalan miyak goreng tersebut.

\section{Pembuatan Perangkat Lunak}

Software dari sistem ditulis menggunakan bahasa C dan compiler yang digunakan adalah CVAVR. Adapun flow chart nya adalah sebagai berikut : 


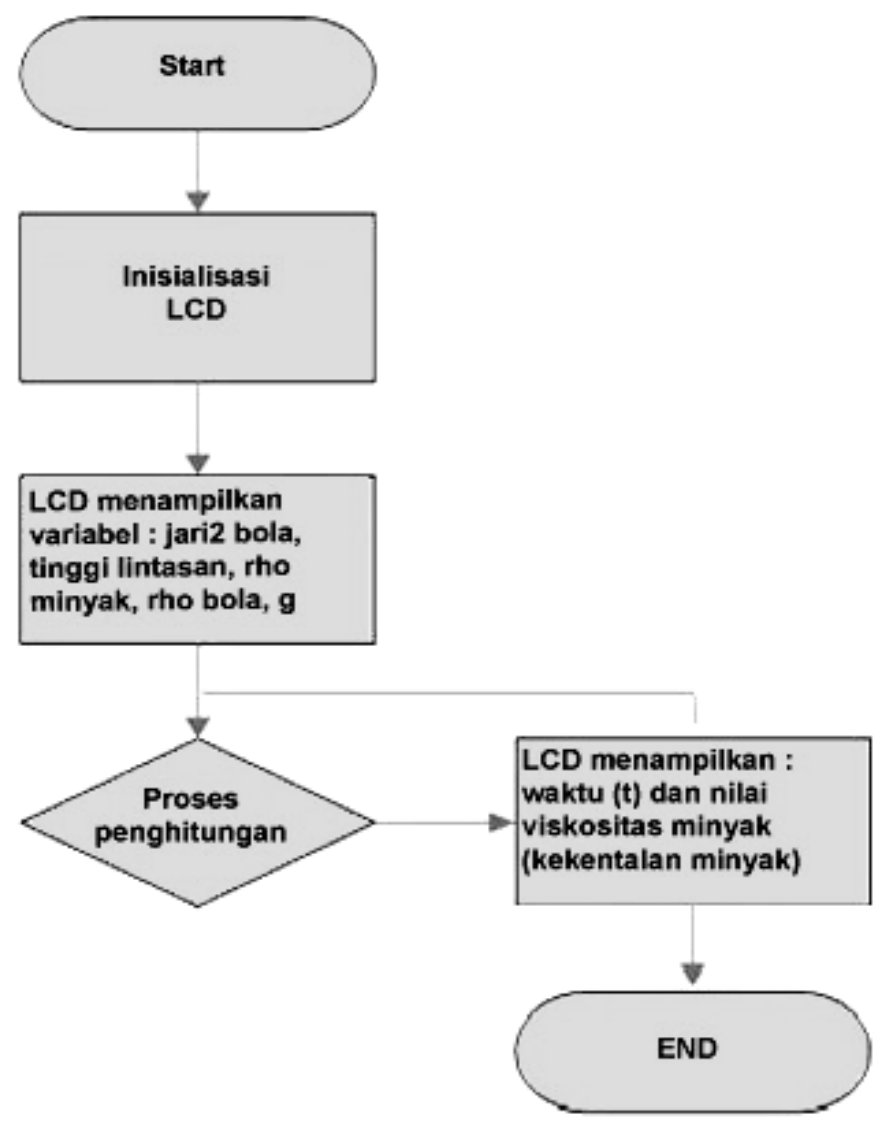

\section{Gambar 2. Flow chart Diagram Sistem}

Pada flow chart diagram tersebut dapat dilihat pada saat pertama kali sistem dihidupkan, sistem melakukan inisialisasi pada LCD. Selanjutnya sistem menampilkan variabel inputan dan menampilkannya pada LCD. Adapun variabel yang akan ditampilkan adalah : 1. massa jenis bola gotri $\left(\mathrm{gr} / \mathrm{cm}^{3}\right)$ 2. massa jenis cairan (minyak) 3. jari-jari bola gotri $(\mathrm{cm}) 4$. tinggi cairan $(\mathrm{cm}) 5$. gravitasi bumi $\left(9,8 \mathrm{~m} / \mathrm{s}^{2}\right)$ 6. waktu tempuh bola jatuh. Setelah memilih menu yang dikehendaki, maka tombol start kita tekan, sehingga sistem akan memerintahkan untuk melepaskan bola gotri dalam tabung. Kemudian bola gotri di deteksi dengan sensor pertama maka waktu mulai berjalan dan setelah terdeteksi sensor kedua maka waktu ber- 
henti, sehingga didapatkan waktu tempuh bola gotri jatuh. Dengan algoritma pemrograman C, maka hasil akan ditampilkan pada layar LCD.

\section{HASIL DAN ANALISA DATA}

Setelah semua rancangan Alat Uji Kekentalan Minyak Goreng dengan Metode Viskositas Stokes untuk Praktikum Fisika Dasar 1Jurusan Tadris Fisika Fakultas Ilmu Tarbiyah dan Keguruan IAIN Walisongo Semarang selesai dibuat, maka langkah selanjutnya adalah menguji alat yang dibuat sudah apakah siap digunakan dan sudah sesuai dengan yang diinginkan.

\section{Hasil Pembuatan Alat Kekentalan Minyak Goreng}

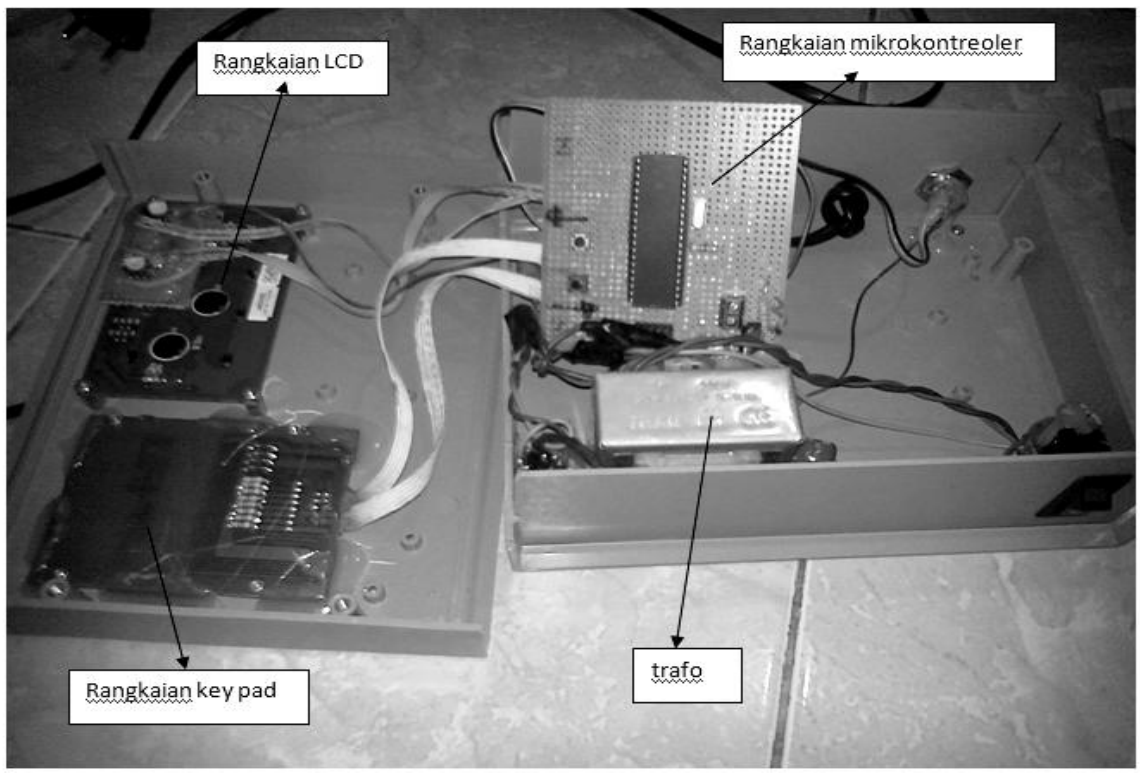

Gambar 3. Gambar rangkaian (mikrokontroler, LCD dan keypad) 


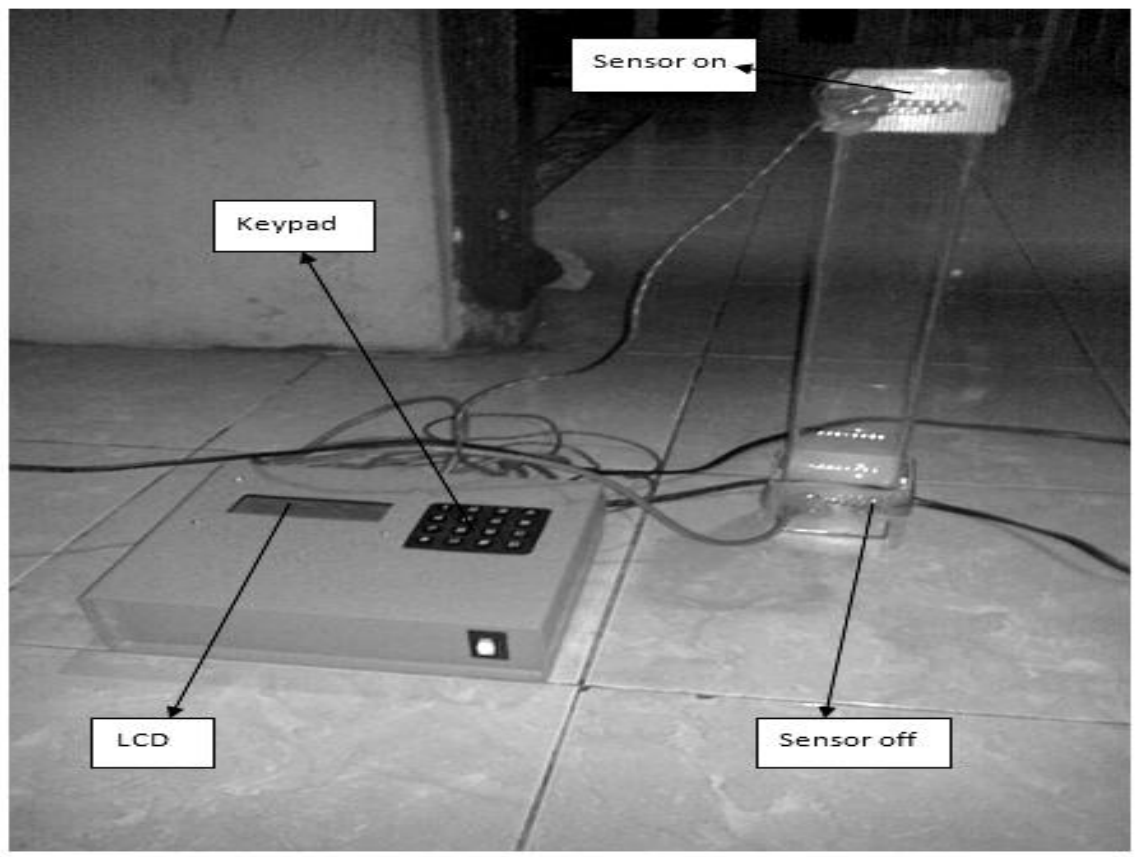

Gambar 4. Gambar keseluruhan alat digitalisasi osilasi cairan

\section{Hasil Pengujian Kekentalan Minyak Goreng}

Minyak goreng yang belum dipakai dan dipakai satu kali yaitu minyak goreng yang sudah digunakan untuk menggoreng selama kurang lebih 5-8 menit. Adapun hasilnya adalah sebagai berikut :

1. Pengujian minyak goreng belum

Tabel 1 hasil pengujian viskositas minyak goreng yang belum dipakai

\begin{tabular}{|c|c|}
\hline Pengujian & Hasil $\eta\left(\mathrm{Ns} / \mathrm{m}^{2}\right) \times 10^{-3}$ \\
\hline $\mathrm{I}$ & $4,80 \pm 0,09$ \\
\hline
\end{tabular}

2. Pengujian minyak goreng dipakai 1 (satu) kali

Tabel 2 hasil pengujian viskositas minyak goreng yang sudah dipakai 1 kali

\begin{tabular}{|c|c|}
\hline Pengujian & Hasil $\eta\left(\mathrm{Ns} / \mathrm{m}^{2}\right) \times 10^{-3}$ \\
\hline $\mathrm{I}$ & $4,62 \pm 0,08$ \\
\hline
\end{tabular}




\section{Analisa Data}

Dari tabel 1 dan 2 dapat dibandingkan bahwa nilai kerapatan dari minyak goreng mengalami penurunan nilai viskositasnya pada minyak goreng yang belum dipakai dan pada minyak goreng yang pernah dipakai satu kali. Minyak goreng yang sudah dipakai satu kali mempunyai nilai kerapatannya mengalami penurunan karena minyak goreng tersebut telah mengalami pemanasan sehingga ikatan antar molekulnya berkurang dan menyebabkan kerapatan minyak berkurang. Minyak goreng yang belum pernah dipakai mempunyai nilai kerapatan besar karena minyak goreng tersebut belum mengalami pemanasan, sehingga molekul-molekulnya tidak mengalami perenggangan dan kerapatannya lebih besar. Jadi, minyak goreng dengan kerapatan besar adalah pada minyak goreng yang belum dipakai, dan kerapatan mengalalmi penurunan yaitu pada minyak goreng yang sudah dipakai satu kali. Viskositas dalam cairan ditimbulkan oleh gesekan dalam lapisan-lapisan dalam cairan, sehingga makin besar gesekan yang terjadi maka viskositasnya semakin besar, begitu juga jika gesekan yang terjadi lebih kecil, maka viskositasnya juga kecil.

\section{KESIMPULAN}

Berdasarkan penelitian yang dilakukan dapat diambil beberapa kesimpulan, yaitu :

1. Viskositas dapat digunakan untuk membedakan kualitas minyak goring dan perubahan viskositas menunjukkan perubahan kualitas minyak goreng.

2. Pada penelitian ini viskositas yang besar menunjukkan minyak goreng mempunyai kualitas yang baik. Nilai viskositasnya yaitu sebesar 4,80×10-3 Ns/ $\mathrm{m}^{2}$.

3. Alat uji kekentalan minyak goring siap dipergunakan untuk praktikum Fisika Dasar 1 pada modul Viskositas Stokes 


\section{DAFTAR PUSTAKA}

Anonim. 2013. LCD. http://www.delta-elektronik. com,DatasheetLCD. dinduh tanggal 28 Juli 2013 pukul 22.00

Anonim. 2013. Viskositas. http:// file.upi.edu/Direktori/FPMIPA/ JUR._PEND._FISIKA/ 196707251992032\%20-\%20SETIYA\%20 UTARI/4_Viskositas.pdf, diunduh tanggal 29 Juli 2013 jam 12.15

Anonim. 2013. http://id.wikipedia.org/wiki/Diode_pancaran_cahaya. diunduh pada tanggal 4 Agustus 2013 pukul 09.00

Anonim. 2013. Keypad. http://delta-electronic.com/article/wpcontent/uploads/2008/09/an0060.pdf. diunduh tanggal 4 Agustus 2013 pukul 20.30

Ketaren, S., 1986. Pengantar Minyak dan Lemak Pangan, UI Press, Jakarta

Lingga. W. 2006. Mikrokontroler AVR Seri ATMega8535 Simulasi, Hardware, dan Aplikasi. Andi Offset. Yogyakarta

Link. Wolfgang. 1993. Pengukuran, Pengendalian dan Pengaturan dengan PC. PT Elexmedia Komputindo. Jakarta

Malvino. A. P. 1992. Prinsip-prinsip dan Penerapan Digital. Erlangga. Jakarta

Sutiah, 2008. Studi Kualitas Minyak Goreng dengan Parameter Viskositas dan Indeks Bias. Skripsi Jurusan Fisika FMIPA UNDIP 